\title{
The European Conformity Assessment Procedures and the Quality Assurance Instruments for Personal Protective Equipment in the Internal Market
}

\author{
Joachim Lambert \\ Berufsgenossenschaftliches Institut für Arbeitssicherheit (BIA) \\ (Institutions for Accident Prevention and Insurance in Industry)
}

\begin{abstract}
Conformity assessment procedures prescribed by European legislation are presented and their concrete implementation is illustrated by the example of personal protective equipment (PPE). The different categories of PPE defined by Council Directive $89 / 686 / E E C$ are explained with reference to the applicable conformity assessment elements. Quality assurance of production is presented as the central element of the conformity assessment procedure for complex PPE. Special emphasis is put on the necessity of having a regular exchange of views and information among notified bodies in Europe. Ways in which third countries can eventually carry out conformity assessment on the basis of a contract with the European Community Commission are explained.
\end{abstract}

internal market European community conformity assessment

personal protective equipment European standardization

quality assurance notified bodies

\section{THE INTERNAL MARKET}

On January 1, 1993, the internal market came into existence in the European Community (EC). The term internal market means an area where the free movement of products, persons, services, and capital is guaranteed. The significance of the internal market for the European economy is reflected in the following figures: Whereas economic centers such as Japan or the United States have 120 million and 240 million inhabitants, respectively, the total number of inhabitants in the EC member states is about 337 million people, which represents an enormous purchasing power. One prerequisite for the realization of the internal market was extensive harmonization of the different national regulations, rules, and standards. The harmonization of regulations is normally done by means of European directives.

\section{SIGNIFICANCE OF EUROPEAN STANDARDIZATION}

As EC directives - according to the New Approach of 1985-stipulate basic requirements only, other ways had to be found to put these requirements into more concrete terms. In this context, standardization plays a decisive role. Standards represent a means to give exact specifications and thus specify the basic requirements of the EC directives relatively quickly, without resorting to complicated legal procedures. It is, however, necessary that these standards apply in all EC member states.

Correspondence and requests for reprints should be sent to J. Lambert, BIA-Berufsgenossenshcaftliches Institut für Arbeitssicherheit, Hauptverband der gewwrblichen Berufsgenossenschften, 53754 Sankt Augustin, Germany. 
European Committee for Standardization/European Committee for Electrotechnical Standardization (CEN/CENELEC) and European Telecommunications Standards Institute (ETSI) standards meet this condition. Harmonized European standards have to be adopted by the national organizations of standardization of the member states. Simultaneously, national standards that conradict EC standards have to be withdrawn. The goal of realizing the internal market by 1993 gave the European standardization activities fresh impetus to a degree no one would have believed possible before; particular efforts were made in the field of personal protective equipment.

\section{CONFORMITY ASSESSMENT PROCEDURES WITHIN THE FRAMEWORK OF COMMUNITY LAW}

According to the European directives, manufacturers must provide a declaration of conformity for all products that are covered by EC directives (Council Decision 93/465/EEC). This declaration is a written confirmation that a given product complies with the relevant directives. Such a product can be recognized easily by supervising authorities and purchasers by means of a CE mark, which must be affixed to the product. By affixing a CE mark and providing a declaration of conformity, manufacturers not only confirm that their products correspond to the safety requirements of the directive, but, in addition, that companies have subjected their products to all assessment procedures foreseen in the directive. The directives determine, for every single case, the assessment procedure that must be performed in order to guarantee the purchaser the product's compliance with general requirements. Depending on the risk level related to the use of a product, these assessment procedures may differ considerably: a simple submission of the technical files, type tests performed by a notified testing laboratory, random sample tests of serial-produced goods, the implementation of a certified quality assurance system, or, in some exceptional cases, individual tests of each manufactured product.

\section{CONFORMITY ASSESSMENT PROCEDURES WITHIN THE FRAMEWORK OF THE DIRECTIVE}

\section{Properties of Personal Protective Equipment (PPE)}

The scope of Council Directive 89/686/EEC of December 21, 1989, the approximation of the laws of the member states relating to PPE covers all PPE. It has to satisfy the basic health and safety requirements laid down in Annex II of the directive. With the transposition of the directive into German law, a transitional period until December 31, 1994 was introduced; during that period, PPE could still be manufactured and put on the market under the old law. In the meantime, an amendment to the directive was published extending the transitional period until June 30, 1995 for all member states (Council Directive 93/95/EEC). The directive distinguishes among three categories of PPE

\section{Category 1}

PPE where the users themselves can assess the level of protection provided against minimal risks. For this PPE category the manufacturer has to compile certain technical documents and keep them at the disposal of supervisory authorities. In addition, they must deliver a declaration of conformity and affix a CE mark to each product.

\section{Categories 2 and 3}

For all other PPE, an EC-type examination by a notified body is compulsory. Within the framework of this examination, the testing laboratory checks the PPE model and the technical documents for their compliance with the basic requirements of the directive. If the results are positive, an EC-type examination certificate is issued. In these cases, the distinguishing number of the notified body that performed the EC-type examination is affixed adjacent to the CE mark.

In the case of a so-called "PPE of complex design" (Category 3 only), which is intended to protect against the danger of death or against dangers that may seriously or irreversibly harm 
health, special additional provisions, relating to the compliance of the serial-produced PPE with the tested specimen, apply. Here, the manufacturer can choose between two procedures:

1. A notified body performs the necessary controls on the serial-produced PPE on a random basis at least yearly and issues a corresponding certificate; or

2. The manufacturer sets up a quality assurance system that must be approved by a notified body. The quality assurance system is supervised by the notified body, which carries out regular audits to make sure the manufacturer maintains and uses the approved quality assurance system.

In this context, it should, however, be emphasized that the problem of PPE classification under one of these categories has given rise to a lively discussion in the EC. It is even foreseeable that one type of PPE, depending on its protection level, will have to be classified under different categories. Protective gloves are one example of this problem:

- Simple protective gloves, for example, for use in the kitchen, are classified under Category 1 ;

- Protective gloves against mechanical risks belong to Category 2; and

- Chemical protective gloves would appear in Category 3.

This example demonstrates the complexity of the problem: A good deal of work and many agreements are still needed.

\section{QUALITY ASSURANCE OF PRODUCTION}

The previously mentioned solution, which consists of setting up a tested, certified, and supervised assurance system, is gaining increasing importance on the European level. It is an element of other directives as well. The modular concept of the EC Commission for checking production conformity, mentions three modules (Modules D, E, and $\mathrm{H}$ ) containing the element of quality assurance (see Figure 1; Council Decision 93/465/EEC). The increased demand for quality assurance systems not only has its roots in European directives, but more and more often, the companies themselves ask their subcontractors to submit proof of quality controlled production.

Developed initially for military reasons, the concept of quality assurance moved away from its original application and was first used in the sector of high-safety applications, such as nuclear power stations, aircraft, spacecraft, and satellite technology, then in mass-product fabrication, for example, in the case of electronic components, and eventually in the consumer goods industry. European directives always introduce some sort of quality assurance for production when unacceptable risks for users or third persons are likely to arise as a result of nonhomogeneous production. The establishment and supervision of quality assurance systems today are generally performed on the basis of the standards series EN 29000 ff., corresponding to ISO $9000 \mathrm{ff}$.

\section{NOTIFIED BODIES}

The European directives mention notified bodies or authorized bodies, which are in charge of either carrying out EC-type examinations and the random control of end products, or of supervising quality assurance systems. These bodies are named to the Commission by member states. Only bodies that comply with certain minimum requirements stipulated in the different directives can be authorized. This is to ensure the member states that the test results are always comparable, regardless of where the test is performed.

This is why, in the mid-1980s, the Commission began to define general criteria for testing laboratories and certification bodies. In the meantime, these criteria, which are largely based 


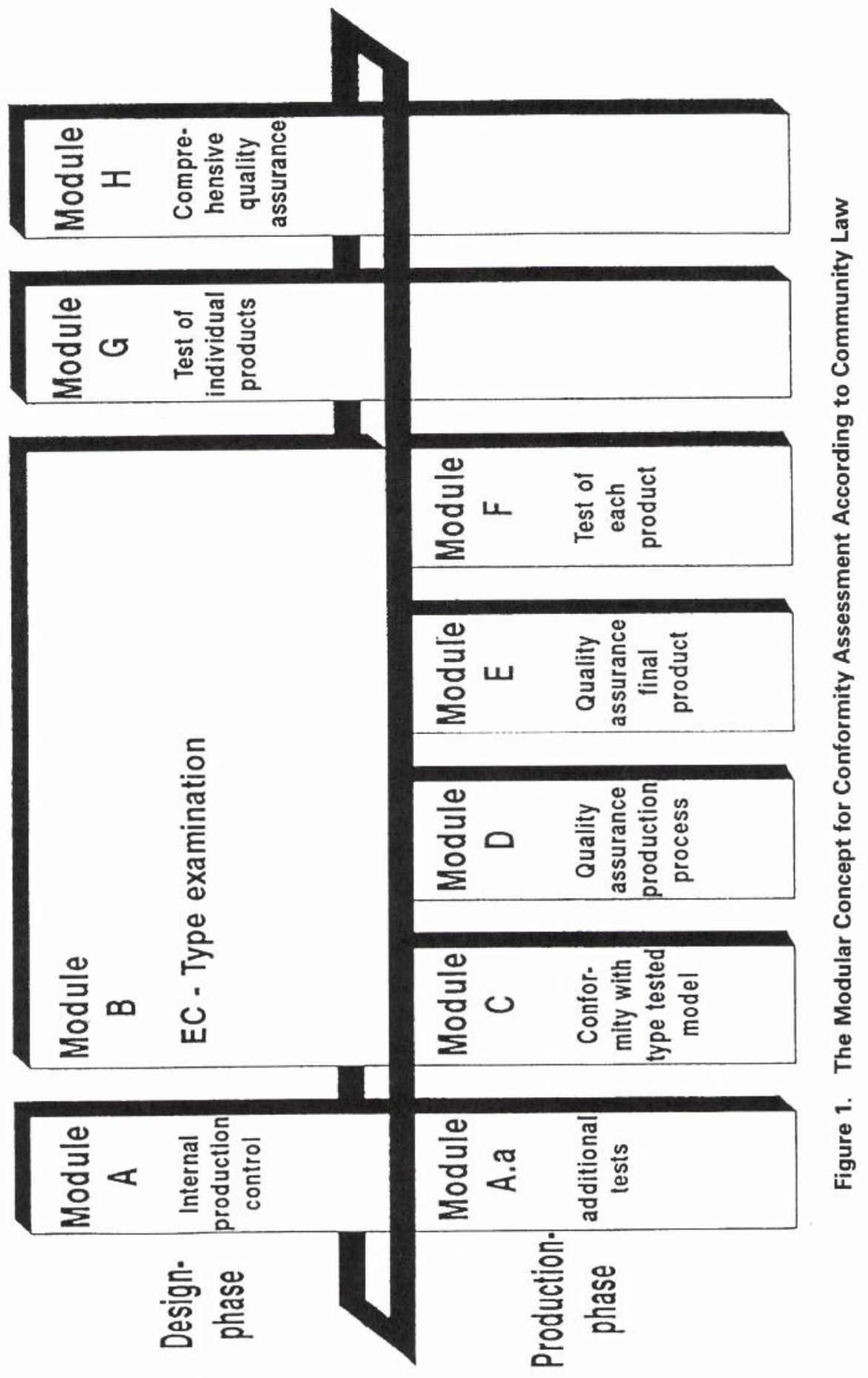


on International Laboratory Accreditation Conference (ILAC) documents, have been summarized in the standards series EN $45000 \mathrm{ff}$. and implemented in the form of integrated standards in the CEN/CENELEC member states. The central requirements mandated in these standards call for the establishment of a documented quality assurance system in testing laboratories and certification bodies on the grounds of the standards series EN $29000 \mathrm{ff}$. Quality inspections of testing laboratories and certification bodies can be carried out directly by national authorities who nominate these bodies to the EC Commission. In many cases, however, a special accreditation procedure is necessary. Here, the accrediting body checks the quality assurance manual and the laboratories as well as the organizational procedures in view of compliance with the requirements of the standards series EN $45000 \mathrm{ff}$. If the result is positive, the body receives accreditation for a defined group of products or test fields for a limited period of time. In Germany such a two-step procedure applies, consisting of accreditation and notification.

The central institute for research and testing of the German Institutions for Accident Prevention and Insurance in Industry (Berufsgenossenschaftliches Institut für Arbeitssicherheit or BIA) was the first testing laboratory and certification body in Germany both to receive accreditation in the field of PPE and to be named to the Commission by the federal government of Germany. Since then, among others, a second testing and certification body of the Berufsgenossenschaften, the expert committee for PPE in Erkrath-Hochdahl II has received accreditation and notification, too.

\section{EXCHANGE OF EXPERIENCE}

Looking at the practical application of testing and certification systems in Germany, one can see that there are always problems for which directives and standards provide no absolute solutions. This creates a situation in which interpretations have to be incorporated through an exchange of experience among notified testing bodies. Thus, it is a matter of course that testing laboratories and certification bodies, after having received accreditation and notification, contribute to a regular exchange of experience and views at the national and European levels. It was the BIA that initiated the European exchange of experience among notified bodies in the PPE field. Five meetings have been held so far, which were well received by the European bodies notified in this field. A system was developed, ensuring the exchange of experiences in the different sectors of PPE through separate vertical working groups on the one hand, and through summarizing all vertical activities in a horizontal structure on the other.

\section{FORTRESS EUROPE?}

The establishment of the internal market was accompanied by a fear which haunted the countries outside the EC: the fear that Europe might become a fortress, that the opening of the internal frontiers would not only facilitate and promote the exchange of goods and services within the EC, but, at the same time, it might obstruct the flow of goods from outside the EC. This has certainly not proven to be the case. The situation that existed before the establishment of the internal market was characterized by a variety of different legal provisions in the European states so that products had to satisfy different requirements depending on the country in which they were sold. This entailed different approval procedures and consequently, different product designs both within the EC and for products imported from countries outside the EC.

By establishing the internal market, a homogeneous European economic region of hitherto unknown size was created not only for the EC states, but for nonmember states, too. This market can now be supplied with the same or similar product versions, thus enabling manufacturers to reduce the number of design variants. It is, of course, necessary to manufacture products corresponding to EC provisions.

In this context, a document published under the reference DOK.CERTIV 91/1-rev.3 by the Directorate General III on November 18, 1991 plays an important role. Its title is "Working documents on negotiations with third countries concerning the mutual recognition of conform- 
ity assessment." Although it is still only a working document and has not yet been adopted by the Council, its basic statements have the member states' approval and it will most likely serve as the basic document for future negotiations with non-EC countries. The following extract is of particular importance:

All products put on the Community market must at least provide the protection level stipulated by the EC directives.

Third countries may perform conformity assessment of their products in their own laboratories and certification bodies.

Agreements must guarantee that bodies entrusted with carrying out conformity assessment in third countries and in the European Community are at comparable levels of competence and responsibility.

An agreement on mutual recognition signed by the Commission applies to the entire area of the Community.

Notifying authorities and notified bodies in third countries have to attend coordination meetings with the Commission and with relevant bodies of the Community [exchange of experience].

If these prerequisites are met, corresponding agreements can be signed between third countries and the EC Commission enabling third countries to take advantage of the large European internal market with its almost 340 million inhabitants and the purchasing power they represent.

\section{REFERENCES}

Council Decision 93/465/EEC of July 22, 1993 concerning the modules for the various phases of the conformity assessment procedures and the rules for the affixing and use of the CE conformity marking, which are intended to be used in technical harmonization directives. Official Journal of the European Communities, No. L 220, August 30, 1993, p. 13

Council Directive 89/686/EEC of December 21, 1989 on the approximation of the laws of the member states relating to personal protective equipment. Official Journal of the European Communities, No. L 399, December 30, 1989, p. 18

Council Directive 93/95/EEC of October 29, 1993 amending Dircctive 89/686/EEC on the approximation of the laws of the member states relating to personal protective equipment. Official Journal of the European Communities, No. L 276, November 9, 1993, p. 11

\section{ADDITIONAL REFERENCES}

DOK.CERTIV 91/1-rev.3 of November 18, 1991, Working documents on negotiations with third countries concerning the mutual recognition of conformity assessment. Published by European Commission, Directorate General III.

ISO $9000 \mathrm{ff}$ Quality management and quality assurance standards (1987)

EN $2900 \mathrm{ff} \quad$ European standards on quality management and quality assurance (identical with ISO $9000 \mathrm{ff}$ ) (1987)

EN $45000 \mathrm{ff}$ European standards on general criteria

- for the operation of testing laboratories (EN 45001:1989)

- for certification bodies operating product certification (EN 45011:1989) 